\title{
Recent International R\&D Activities in the Extraction of Uranium from Seawater
}

\author{
Linfeng Rao \\ Chemical Sciences Division \\ Lawrence Berkeley National Laboratory \\ Berkeley, CA 94720
}

March 15, 2010

\begin{abstract}
DISCLAIMER
This document was prepared as an account of work sponsored by the United States Government. While this document is believed to contain correct information, neither the United States Government nor any agency thereof, nor The Regents of the University of California, nor any of their employees, makes any warranty, express or implied, or assumes any legal responsibility for the accuracy, completeness, or usefulness of any information, apparatus, product, or process disclosed, or represents that its use would not infringe privately owned rights. Reference herein to any specific commercial product, process, or service by its trade name, trademark, manufacturer, or otherwise, does not necessarily constitute or imply its endorsement, recommendation, or favoring by the United States Government or any agency thereof, or The Regents of the University of California. The views and opinions of authors expressed herein do not necessarily state or reflect those of the United States Government or any agency thereof or The Regents of the University of California.
\end{abstract}

This work was supported by the Office of Nuclear Energy, the Fuel Cycle Research and Development Program, of the U.S. Department of Energy under Contract No. DE-AC02$05 \mathrm{CH} 11231$ 


\title{
Recent International R\&D Activities in the Extraction of Uranium from Seawater
}

\author{
Linfeng Rao \\ Lawrence Berkeley National Laboratory \\ Berkeley, California
}

\section{Summary}

A literature survey has been conducted to collect information on the International R\&D activities in the extraction of uranium from seawater for the period from the 1960s till the year of 2010. The reported activities, on both the laboratory scale bench experiments and the large scale marine experiments, were summarized by country/region in this report. Among all countries where such activities have been reported, Japan has carried out the most advanced large scale marine experiments with the amidoxime-based system, and achieved the collection efficiency $(1.5 \mathrm{~g}-\mathrm{U} / \mathrm{kg}$-adsorbent for 30 days soaking in the ocean) that could justify the development of industrial scale marine systems to produce uranium from seawater at the price competitive with those from conventional uranium resources.

R\&D opportunities are discussed for improving the system performance (selectivity for uranium, loading capacity, chemical stability and mechanical durability in the sorptionelution cycle, and sorption kinetics) and making the collection of uranium from seawater more economically competitive.

\section{Background}

The total amount of uranium resource in seawater is about 4.5 billion tons ([U] $\sim 3 \mathrm{ppb}$, ocean volume $\sim 1.37 \times 10^{9} \mathrm{~km}^{3}$ ), one thousand times of the amount of uranium in terrestrial ores. However, there are two major obstacles to using this virtually limitless reservoir as an economic source of uranium: 1) the uranium is in a strongly complexed form (carbonate complexes) at extreme dilution in the presence of relatively high concentrations of other ions; 2 ) it is a very difficult operation to bring any extraction agent into contact with very large volumes of seawater that would be involved. To be successful, the extractant must function efficiently at the seawater $\mathrm{pH}$ and ionic strength, and must be virtually insoluble (1).

\section{R\&D Activities by Country/Region}

\subsection{Japan}

\subsubsection{Earlier studies}

The extraction of uranium from seawater was studied by the Japan Tobacco and Salt Corporation in the 1960s. Since then, the National Institute of Advanced Science and Technology (Shikoku), the University of Tokyo, Kyoto University and other research institutes have carried out laboratory experiments. In 1974, the Research Committee on Rare Resources from Seawater was organized in the Ministry of International Trade and Industry (MITI) to start overall study of uranium recovery from seawater. In 1975, the Metal Mining Agency of Japan participated in the project, and established a coordinating committee (2), 
The earlier studies focused on evaluation of different methods (solvent extraction, ion exchange, flotation, biomass collection, adsorption), and development of adsorbents (hydrous $\mathrm{TiO}_{2}, \mathrm{PbS}$ ) (3).

Solvent extraction, though feasible, is considered to be unsuitable for the extraction of uranium from seawater on a large scale, due to the requirements of complicated engineering setup/procedure and large amounts of chemicals and volatile solvents, and the problem of solvent loss by entrainment and dissolutin $(3,4)$.

Ordinary organic ion exchange resins, such as the resorcinol arsenic acid formaldehyde or 8-hydroxyquinoline resin, show good uptake of uranium, but their rapid deterioration with aging makes them unsuitable for the extraction of uranium from seawater $(3,4)$. Some macrocyclic polydentate ligands were studies to improve the selectivity $(3,4)$, but no further development work was reported in the later literature for unclear reasons. For example, polymer-bound macrocyclic hexaketone (Figure 1) was found to be capable of extract uranyl ion from seawater (4). However, the study was not continued probably because the drawbacks such as slow kinetics and potential loss of the chelating agent precluded its further development.

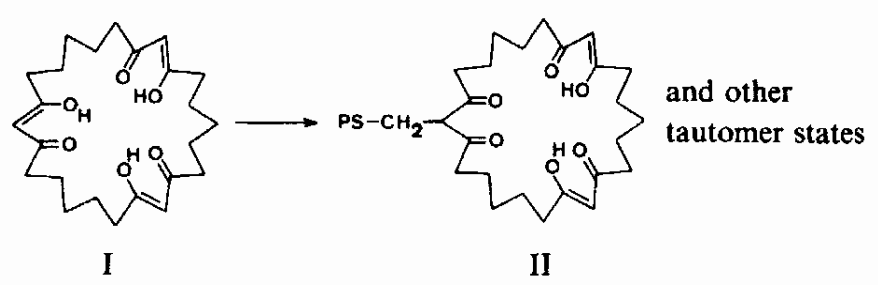

Figure 1. Hexaketone ligand for the complexation of $\mathrm{U}(\mathrm{VI})(3,4)$.

Several types of biological substances have been reported to be used for uranium extraction, including acid polysaccharides, phosphorylated polysaccharides (chitin phosphate, chitosan phosphate, cellulose phosphate). However, the adsorption capacity is low and there are problems of contacting microorganism with seawater and their collections $(3,4)$.

The earlier studies indicated that hydrous $\mathrm{TiO}_{2}$ was a promising adsorbent for the collection of uranium from seawater. From 1981 to 1988 , the first experimental plant for collection of uranium from seawater with hydrous $\mathrm{TiO}_{2}$ was operated by the Agency for Natural Resource and Energy (ANRE), MITI, and Metal Mining Agency of Japan. The reported adsorption ability of the hydrous titanium oxide, $0.1 \mathrm{~g}-\mathrm{U} / \mathrm{kg}$-adsorbent, was too low for practical applications and should be improved at least 10 times in order to make the process economical. Also, significant loss of the adsorbent in the process as well as the consumption of electricity for pumping seawater increased the collection cost. Additionally, the hydrous $\mathrm{TiO}_{2}$ adsorbent is not mechanically strong enough for the wearing motion in the moving bed system.

\subsubsection{Recent studies}

Recent studies in Japan have been focused on the amidoxime-based adsorbent system. Both laboratory studies and marine experiments in the Pacific Ocean have been conducted. The laboratory studies cover the preparation of amidoxime-based adsorbents, the equilibrium of the uranium uptake, and the kinetics and mechanism of the extraction of uranium from seawater (4-16). Collection of uranium with chitosan-resin and biomass such as algae was also performed $(17,18)$. The marine experiments were 
performed by using two types of collection systems: the stack system and the braid system $(19,20)$.

\section{Laboratory studies}

$R \& D$ activities on the laboratory scale were carried out in Japan to develop absorbents for practical applications to the seawater system and three types of amidoxime-based adsorbents were developed (19):

I. Amidoxime-based polymer beads: polymer beads having cyano groups were first synthesized, and then converted to amidoxime groups by reacting with hydroxylamine. The beads type adsorbent needs a package for feasible handing and for effective contact between adsorbent and seawater.

II. Amidoxime-based fiber prepared by a chemical route: This type of amidoxime fiber materials, developed by the National Institute of Advanced Science and Technology, was prepared by reacting commercially available acrylonitrile fiber with hydroxylamine. The adsorbents can utilize the ocean current and the wave motion when it is moored in the sea. However, because the amidoxime groups were imparted evenly in the fiber and the intrinsic mechanical strength of fiber was lost after amidoximation, the amidoxime fiber prepared by the chemical route is not mechanically strong enough for mooring in the seawater.

III. Amidoxime-based fiber prepared by radiation-induced graft polymerization: As shown in Figure 2, polyethylene was irradiated with electron beam and acrylonitrile was grafted onto polyethylene non-woven fabrics. Subsequently, the cyano group of the grafted polymer chain was converted into the amidoxime group. This grafting led the production of adsorbent having enough mechanical strength and high capacity of uranium adsorbent.

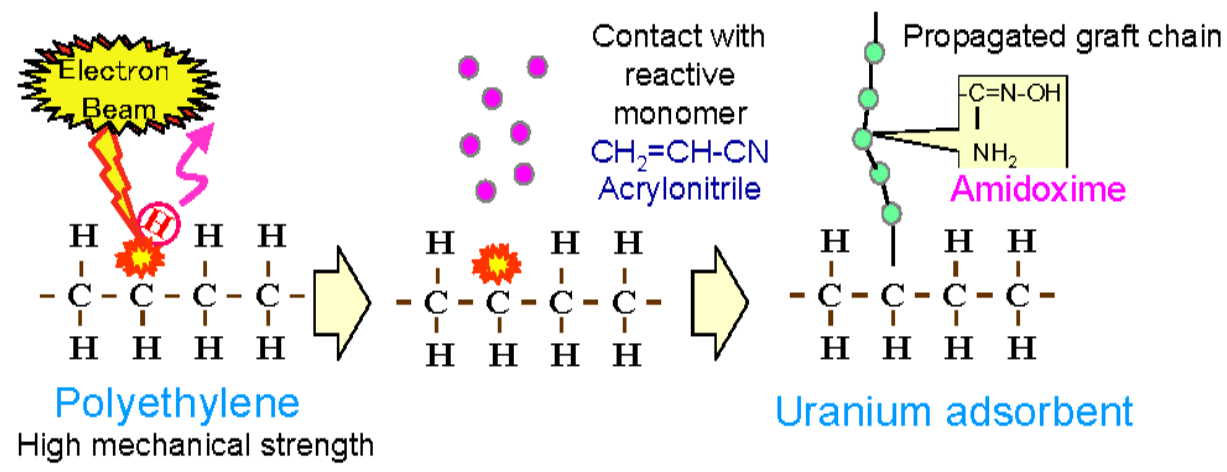

Figure 2. Amidoxime-based fiber prepared by radiation-induced graft polymerization (19).

The adsorption of uranium and other metals by the amidoxime-based fiber from seawater is shown in Table 1. 
Table 1. Selectivity of the amidoxime adsorbent (19).

\begin{tabular}{cccc}
\hline Elements & $\begin{array}{c}\text { Concentration } \\
\text { in seawater } \\
{[\mu \mathrm{g} / \mathrm{L}]}\end{array}$ & $\begin{array}{c}\text { Concentration } \\
\text { in adsorbent }^{\mathrm{b}} \\
{[\mu \mathrm{g} / \mathrm{g} \text {-ad }]}\end{array}$ & $\begin{array}{c}\text { Distribution } \\
\text { coefficient } \\
(\mathrm{b} / 1000 \mathrm{a})\end{array}$ \\
\hline $\mathrm{Na}$ & $1.08 \times 10^{7}$ & 618.5 & 0.057 \\
$\mathrm{~K}$ & $3.80 \times 10^{5}$ & 45.9 & 0.12 \\
$\mathrm{Al}$ & 2 & 86.94 & $4.35 \times 10^{3}$ \\
$\mathrm{~Pb}$ & 0.03 & 108.82 & $3.62 \times 10^{6}$ \\
$\mathrm{Ti}$ & 1 & 1.49 & $1.49 \times 10^{3}$ \\
$\mathrm{Fe}$ & 2 & 414.44 & $2.07 \times 10^{5}$ \\
$\mathrm{Co}$ & 0.05 & 23.57 & $4.71 \times 10^{5}$ \\
$\mathrm{Ni}$ & 1.7 & 78.17 & $4.60 \times 10^{4}$ \\
$\mathrm{U}$ & 3.2 & 63.72 & $1.99 \times 10^{4}$ \\
\hline
\end{tabular}

Adsorption conditions: $0.2 \mathrm{~g}$ adsorbent $25^{\circ} \mathrm{C}, 3 \mathrm{~L} / \mathrm{min}$ seawater, and 7 days.

\section{Marine experiments}

Type III of the amidoxime-based fiber was used in the marine experiments in Japan. Two types of marine experiments have been carried out: (1) uranium collection system using amidoxime adsorbent stacks $(19,20)$; (2) uranium collection system using amidoxime braid adsorbent (19).

The stack collection system. The results of the marine experiments using the stack collection system are summarized in two references $(19,20)$. The collection system is shown in Figure 3. It is composed of a floating flame and adsorption beds. The floating frame was stabilized with ropes connoting to four $40 \mathrm{t}$-anchors placed on the sea bottom. Three square adsorption beds, $16 \mathrm{~m}^{2}$ in cross-sectional area and $30 \mathrm{~cm}$ in height, can each pack 144 adsorbent stacks. The adsorbent stacks were assembled by 120 sheets of adsorbent fabrics $(0.2 \mathrm{~cm}$ thick, $16 \mathrm{~cm}$ wide and $29 \mathrm{~cm}$ long) alternately with spacer nets and hanged in seawater from the floating frame in the sea depth of $20 \mathrm{~m}$. The frame was designed to endure the following ocean weather conditions: wind strength of $30 \mathrm{~m} / \mathrm{s}$, tidal current of $1.0 \mathrm{~m} / \mathrm{s}$, and wave height of $10 \mathrm{~m}$.

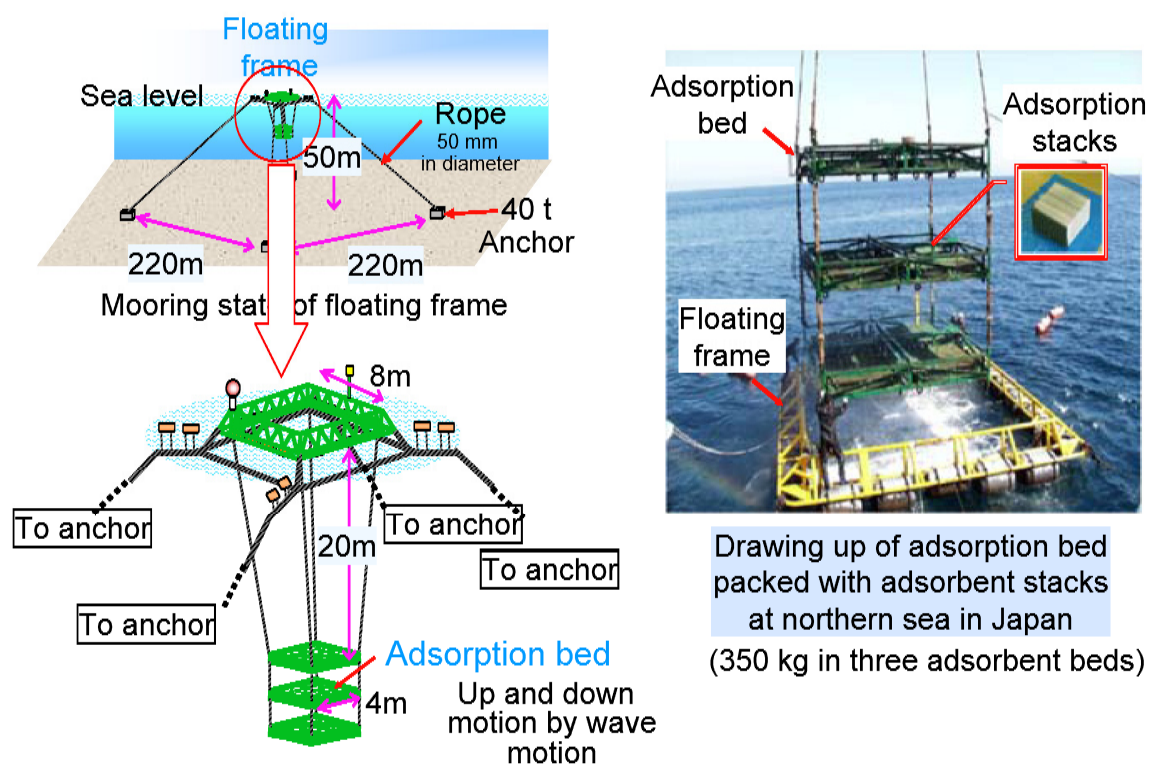

Figure 3. Collection of uranium from seawater using the adsorbent stacks (19). 
The uranium collection experiment using absorbent stacks was performed in the Pacific Ocean at $7 \mathrm{~km}$ offshore from Mustu-Sekine in Aomori prefecture of Japan from 1999 to 2001. The sea depth of this site was approximately $40 \mathrm{~m}$. Adsorbed uranium on adsorbent fabric was fractionally eluted by $0.5 \mathrm{M}$ hydrochloric acid. The average uptake of uranium was $0.5 \mathrm{~g}-\mathrm{U} / \mathrm{kg}$-ad for 30 days' soaking. Total amount of uranium collected by this demonstration reached roughly one kilogram in terms of yellow cake during a total submersion time of 240 days in the ocean. Detailed data of the uranium uptake are shown in Table 2.

Table 2. Uranium uptake in the marine experiments using the stack system (20).

\begin{tabular}{|c|c|c|c|c|c|}
\hline Submersion Period & $\begin{array}{l}\text { Submersion } \\
\text { Time } \\
\text { (day) }\end{array}$ & $\begin{array}{l}\text { Number } \\
\text { of Stacks }\end{array}$ & $\begin{array}{c}\text { Seawater } \\
\text { Temperature } \\
\left({ }^{\circ} \mathrm{C}\right)\end{array}$ & $\begin{array}{l}\text { Amount of } \\
\text { U Adsorbed } \\
\text { (g) }\end{array}$ & $\begin{array}{c}\text { Apparent } \\
\text { Adsorbent Rate } \\
{[\mathrm{g} /(\text { day } \cdot \text { stack })]}\end{array}$ \\
\hline $\begin{array}{l}1999 \\
29 \text { Sep to } 20 \text { Oct }\end{array}$ & 20 & 144 & 19 to 21 & 66 & 0.023 \\
\hline $\begin{array}{l}2000 \\
8 \text { Jun to } 28 \mathrm{Jun} \\
28 \mathrm{June} \text { to } 8 \mathrm{Aug} \\
8 \text { Aug to } 7 \mathrm{Sep} \\
7 \mathrm{Sep} \text { to } 28 \mathrm{Sep} \\
28 \mathrm{Sep} \text { to } 19 \mathrm{Oct}\end{array}$ & $\begin{array}{l}20 \\
40 \\
30 \\
20 \\
20\end{array}$ & $\begin{array}{l}144 \\
144 \\
144 \\
144 \\
144\end{array}$ & $\begin{array}{l}12 \text { to } 13 \\
13 \text { to } 22 \\
22 \text { to } 24 \\
22 \text { to } 24 \\
18 \text { to } 22\end{array}$ & $\begin{array}{r}47 \\
66 \\
101 \\
76 \\
77\end{array}$ & $\begin{array}{l}0.016 \\
0.011 \\
0.023 \\
0.026 \\
0.027\end{array}$ \\
\hline $\begin{array}{l}2001 \\
15 \mathrm{Jun} \text { to } 17 \mathrm{Jul} \\
15 \mathrm{Jun} \text { to } 20 \mathrm{Aug} \\
15 \mathrm{Jun} \text { to } 21 \mathrm{Sep} \\
18 \mathrm{Jul} \text { to } 20 \mathrm{Aug} \\
18 \mathrm{Jul} \text { to } 21 \mathrm{Sep} \\
20 \mathrm{Aug} \text { to } 21 \mathrm{Sep}\end{array}$ & $\begin{array}{l}30 \\
60 \\
90 \\
30 \\
60 \\
30\end{array}$ & $\begin{array}{r}216 \\
72 \\
72 \\
216 \\
144 \\
216\end{array}$ & $\begin{array}{l}13 \text { to } 18 \\
13 \text { to } 20 \\
13 \text { to } 19 \\
18 \text { to } 20 \\
18 \text { to } 19 \\
19 \text { to } 20\end{array}$ & $\begin{array}{r}95 \\
48 \\
120 \\
119 \\
150 \\
118\end{array}$ & $\begin{array}{l}0.015 \\
0.011 \\
0.019 \\
0.018 \\
0.017 \\
0.018\end{array}$ \\
\hline Total & & 1800 & & 1083 & \\
\hline
\end{tabular}

"Amount in terms of yellow cake.

The variation of the apparent adsorption rate (the last column of Table 2) is supposed to be due to the difference in seawater temperature, the wave and tidal motions of the adsorption cages, and the elution history of the amidoxime adsorbent (20).

Data in Table 2 may suggest that the uranium adsorption is correlated with the temperature of seawater and the warming of seawater enhances the chemical adsorption of uranium on the adsorbent (19). It is not clear whether the temperature effect on the sorption, if it is confirmed, is due to the thermodynamics or kinetics of the sorption.

One problem with the stack collection system was biofouling on the surface of the stacks. Biofouling included adhesion and subsequent growth of marine microorganisms and algae. By immersing the stacks in fresh water after the stacks were taken out from the adsorption cage, most of the marine microorganisms could be removed because the drastic decrease in the ionic strength induced the detachment of these marine microorganisms from the surface of the stacks.

Another drawback of the stack collection system is the high collection cost. It is estimated that, If the floating frame and the adsorption beds can be deleted, the total cost could be reduced by $40 \%$ (19).

The braid collection system. The braid collection system was developed to reduce the total collection cost and was evaluated in marine experiments in the sea of Okinawa area of Japan. A schematic image of the braid adsorbent is shown in Figure 4. 


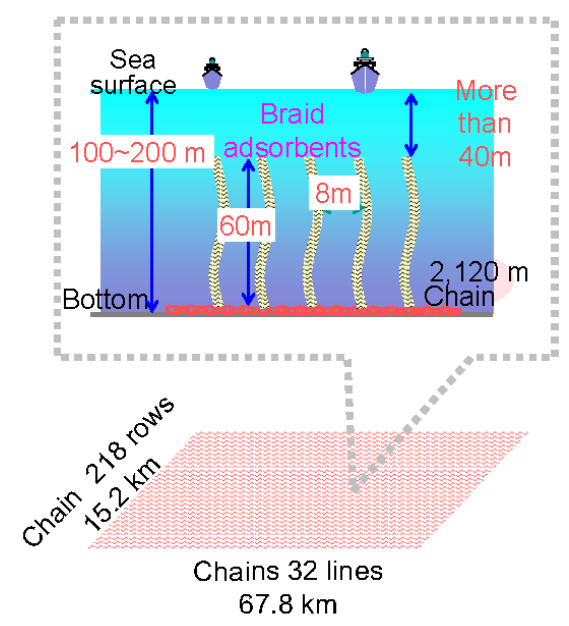

Figure 4. Schematic image of the braid collection system (19).

After the braid adsorbent was thrown into the sea, it simultaneously stood on the sea bottom. When collected, it was cut off from the anchor using wireless operation. The braid adsorbent that appeared on the sea surface was recovered by fishing boat.

Figure 5 shows that the uranium uptake by the braid system was $1.5 \mathrm{~g}-\mathrm{U} / \mathrm{kg}$-ad for 30 days' soaking at $30{ }^{\circ} \mathrm{C}$ in the Okinawa area $\left(10{ }^{\circ} \mathrm{C}\right.$ higher than that of Mutsu area for the stack experiments). Taking into consideration of the difference in temperature, the adsorption ability of the braid system appeared to be 2 times that of the stack system, probably owing to the better contact between seawater and the braid adsorbent.

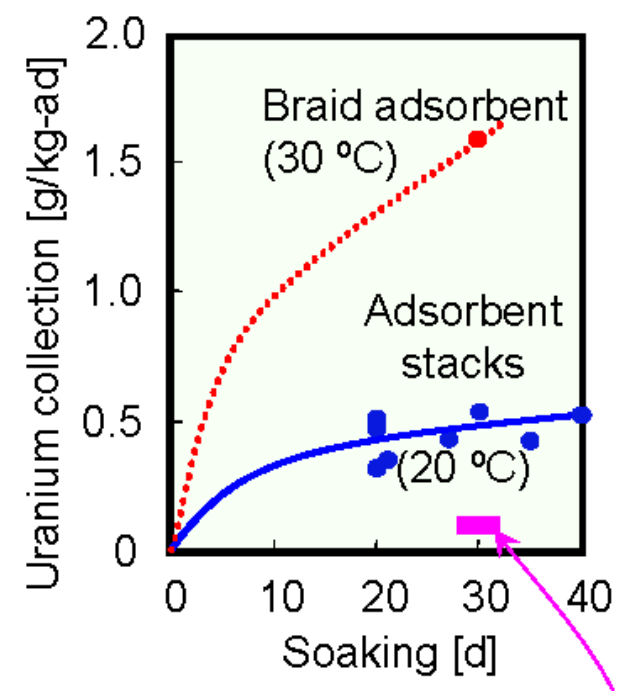

Figure 5. Comparison of uranium collection by different collection systems: red dotted line - braid; blue solid line - stacks; arrow pointed magenta rectangle - hydrous $\mathrm{TiO}_{2}(19)$.

Cost estimation. The uranium collection cost includes processes of adsorbent production, uranium collection, and purification. A rough estimate was made for the amidoxime-based braid collection system, based on the following assumptions: 
- The adsorption ability is $4 \mathrm{~g}-\mathrm{U} / \mathrm{kg}$-ad for 60 days' soaking. This is the highest ability observed in the Okinawa experiment.

- $1,000 \mathrm{~km}^{2}$ sea area near the Japan Current is covered by the braid adsorbents (60 $\mathrm{m}$ length, with the internal spacing of $8 \mathrm{~m}$ ) at the depth from $100 \mathrm{~m}$ to $200 \mathrm{~m}$.

- Uranium is collected on the scale of 1,200 t-U/y.

- The braid adsorbents can be repeatedly used without deteriorating performance. In the laboratory experiment, the repetition of 8 times was achieved.

The estimated collection cost is 32,000 yen/ $\mathrm{kg}-U$ with the currently confirmed repetition use of 8 times. If the repetition is 18 times, the collection cost will be expected to be 25,000 yen/kg-U.

\subsubsection{Current status}

Efforts are being made to secure funding to construct the large scale uranium collection farm, carry out new marine experiments in large scale, and promote the industrialization process. The farm will cover nearly 400 square miles $\left(\sim 1000 \mathrm{~km}^{2}\right)$ that would meet onesixth of Japan's annual uranium requirements (21).

The marine experimental equipments have already been dismantled. The uranium adsorbents are soaked into tanks of seawater and adsorption data are continuously collected. Up to the time of preparing this summary report, the required funding for the large scale farm has not been obtained (22).

\subsection{India}

\subsubsection{Laboratory studies}

Laboratory studies are conducted by two groups in BARC (Bhabha Atomic Research Centre, Mumbai, India), one group in the Radiochemistry Division, and the other in the Desalination Division). The studies are focused on the amidoxime based absorbent systems, in the forms of membranes (23) or hydrogels (24). Other systems with resin or magnetic particles grafted with ligands (such as amidoxime or calixarene) are also proposed (25). The work reported by the group in the Desalination Division was carried out under the specific collaboration agreement between the BARC and the CEA (Commissariat à l'Energie Atomique of France).

The amidoximated macroporous membranes (AO membranes, $2 \mathrm{~cm} \times 1 \mathrm{~cm} \times 2 \mathrm{~mm}$ ) were prepared by post irradiation grafting of acrylonitrile (AN) onto thermally bonded non-woven matrix of poly(propylene) sheet using electron beams. These precursor membranes were reacted with hydroxylamine to convert AN to AO groups, and conditioned by treating them with $2.5 \% \mathrm{KOH}$ at $80^{\circ} \mathrm{C}$ for $1 \mathrm{~h}$. The expected functional group density based on the degree of AN grafting (125 wt.\%) and its subsequent conversion to $\mathrm{AO}$ groups $(80 \%)$ was found to be $7.8 \times 10^{-3} \mathrm{~mol} / \mathrm{g}$. In the batch experiments with ${ }^{233} U$ spiked in seawater, $(96 \pm 3) \%$ of the ${ }^{233} U$ was sorbed by the membrane. The comparison of the expected functional group density and uranium uptake capacity seems to suggest that $\mathrm{UO}_{2}{ }^{2+}$ forms a complex with $\mathrm{AO}$ groups in 1:4 proportion (Figure 6) (23). 


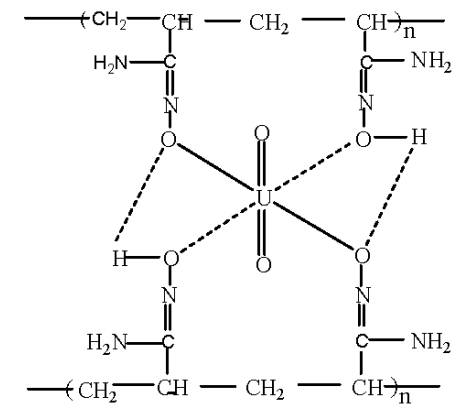

Figure 6. Proposed structure of the $1: 4 \mathrm{UO}_{2}{ }^{2+} /$ Amidoxime complex (23).

In the batch experiments with the membrane, the equilibrium time for sorption saturation was about $200 \mathrm{~min}$. The long equilibrium time could be due to the diffusion of uranium species in the membrane matrix and the reaction kinetics involved in the dissociation of $\left[\mathrm{UO}_{2}\left(\mathrm{CO}_{3}\right)_{3}\right]^{4-}(26)$ and subsequent complexation of $\mathrm{UO}_{2}{ }^{2+}$ with the $\mathrm{AO}$ groups in the membrane. However, the data obtained in this work are not sufficient to identify the rate determining step.

The uranium could be quantitatively desorbed (>90\%) from the $A O$ membrane in $\mathrm{Na}_{2} \mathrm{CO}_{3}$ and mineral acids like $\mathrm{HCl}$ in the equilibration times of $60 \mathrm{~min}$ and $40 \mathrm{~min}$, respectively. Alkaline conditioning was found to be necessary for reuse of the membrane equilibrated with acid. However, $\mathrm{AO}$ membranes equilibrated with $\mathrm{Na}_{2} \mathrm{CO}_{3}$ could be reused without any conditioning for uranium sorption (23).

In the batch experiments with the cross-linked AO-based hydrogels, the hydrogels were prepared with $A O$ and different acidic (acrylic acid (AA), methacrylic acid (MAA), ethylene glycol methacrylate phosphate (EGMP), 2-acrylamido-2-methyl-1-propane sulfonate (AMPS)) and basic (3-(acrylamido propyl)trimethylammonium chloride (APTAC)) co-monomers by UV-initiated bulk polymerization. The objectives are to test the effect of the hydrogel composition on the selectivity and the rate of the sorption of uranium from seawater (24).

The results indicated that the presence of weak acid co-monomer like MAA with AO enhances the selectivity as well as the kinetics of $U(V I)$ sorption from seawater. The kinetics of uptake of $U(V I)$ from seawater was found to be highly dependent on the proportion of MAA and $A O$ in the hydrogel. The presence of a strong acid $\left(-\mathrm{SO}_{3} \mathrm{H}\right)$ or strong base $\left(-\mathrm{N}^{+}\left(\mathrm{CH}_{3}\right)_{3}\right)$ as a co-monomer with $\mathrm{AO}$ retards the overall kinetics involved in the $\mathrm{U}(\mathrm{VI})$ sorption from seawater. Among the hydrogels under investigation, EGMP hydrogel sorbed $\mathrm{U}(\mathrm{VI})$ quantitatively from seawater as well aqueous feed containing high acid concentration. The advantages of EGMP-hydrogel would be as follows: (i) one step synthesis using a single monomer, no hydroxylamine and alkali treatment are required; (ii) unlike acrylonitrile, EGMP is neither volatile nor toxic; (iii) EGMP is readily polymerizable; (iv) under identical seawater conditions, the profile of $U(\mathrm{VI})$ sorption kinetics is faster in EGMP hydrogel as compared to $A O$ and AO/acid co-monomer hydrogels; and (v) EGMP hydrogel can be used for preconcentration of $U(\mathrm{VI})$ from the seawater as well as aqueous feed having high acidity (24).

\subsubsection{Engineering/pilot plant studies}

Under a collaborative project between BARC and CEA, work was conducted to extract uranium from the concentrated brine rejected by desalination plants in $\operatorname{BARC}(25,27)$. An 
R\&D program called RUSWapp (Recovery of Uranium from Sea Water pilot programme) in BARC was initiated (27).

The effluent rejected from the desalination plant contains a number of materials and is a source for many chemicals. Recovery of some of the rare and valuable elements (including uranium) from the rejected brine of the desalination plant helps to make the desalination plant more environment-friendly and reduce the cost of desalinated water.

The present scenario under RUSWapp is to use AO based polymers. Three methods have been proposed: 1) Resin grafted with calixarene (Figure 7): this method could have the advantage of very high selectivity. Its performances, especially for large-scale extraction, still need further R\&D and optimization; 2) Magnetic separations using magnetic particles grafted with calixarene or AO ligands: this method could have the advantages of high selectivity, easy separation and high degree of material recovery. However, it is still in an early developmental stage; 3) Canal system with braid AO adsorbents: this method, similar to that developed in Japan, appears to be selective and feasible in conjunction with existing technology (25).

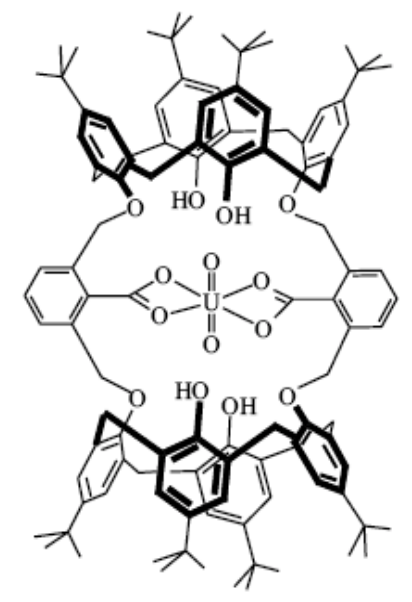

Figure 7. $\mathrm{UO}_{2}{ }^{2+}$-calixarene complex (25).

In the studies with the braid AO adsorbents, experimental data concerning the effect of immersion depth, degree of alkalination, bio and dirt fouling and tidal wave velocity on uranium sorption efficiency were collected at four locations:

- CIRUS Jetty head

- Kalapakkam, near seawater intake tunnel

- Tarapur 1\&2 Seawater intake and outfall canals

- Andaman \& Nicobar Islands

A total of about $800 \mu \mathrm{g}$ of $U$ was collected in 5 campaigns from CIRUS Jettyhead, about $1.8 \mathrm{mg}$ from TAPS seawater intake and outfall canals and around $200 \mu \mathrm{g}$ from Andaman \& Nicobar Islands. The specific collection was found to be from 60 to $160 \mu \mathrm{g} / \mathrm{g}$ of PAO in 12 to 24 days. In comparison, Japanese researchers reported an equilibrium value of $1000 \mu \mathrm{g} / \mathrm{g}$ of $\mathrm{PAO}$ in 52 days at $25^{\circ} \mathrm{C}$ under laboratory conditions. It was observed that vanadium also gets collected on the adsorbent (27).

The BARC 2006-2007 report (27) mentions that a pilot plant facility for 100 grams $U$ per year (RUSWapp100) is under installation (Figure 8). Information on the current status of the pilot plant is not available. 


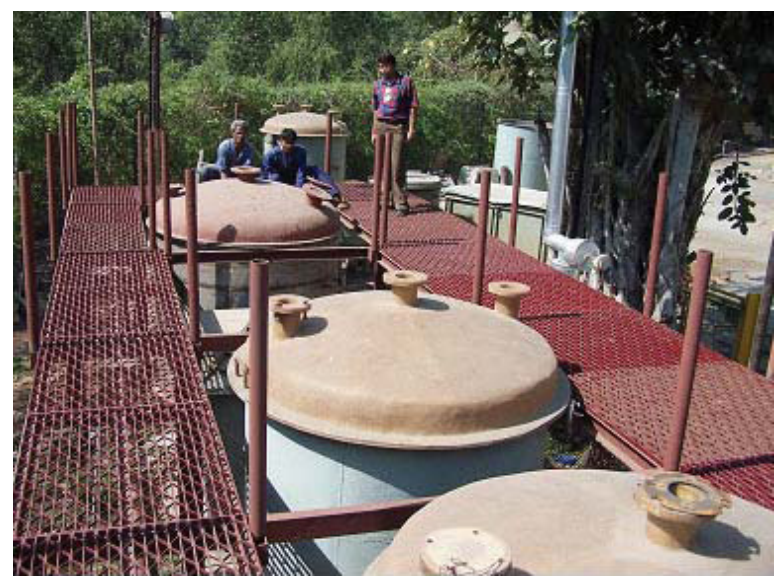

Figure 8. Pilot plant facility (under construction) for uranium recovery from seawater (27).

\subsection{China}

Studies on the extraction of uranium from seawater were initiated in mid-1970's (28). The research activities were mainly conducted in the institutes for research in oceanic sciences or environmental protection, and focused on testing absorbents and understanding the kinetics and mechanism of absorption (29-32). No work on the engineering setup or pilot-plant tests for the extraction of uranium from seawater has been found in the literature.

Hydrous titanium oxide, aluminum hydroxide, and organic resins were among the absorbents tested in late 1970's - early 1980's. More recently, studies with polyacrylamidoxime (33) and chitin (34) for the extraction of uranium from seawater have been discussed in the literature.

Chitin $\left(\mathrm{C}_{8} \mathrm{H}_{13} \mathrm{NO}_{5}\right)_{n}$ (Figure 9) is a cellulose-like biopolymer consisting predominantly of unbranched chains of $\beta$ - $(1,4)-2$-acetamido-2-deoxy-D-glucose (also named N-acetyl-Dglucosamine) residues. It is found in fungi, yeasts, marine invertebrates and arthropods, where it is a principal component in the exoskeletons. Chitin may be regarded as a derivative of cellulose, in which the C-2 hydroxyl groups have been replaced by acetamido residues. It forms colored complexes with a variety of metal ions and can be used to extract novel metals. For example, its phosphate derivatives could extract uranium from seawater (up to $2.6 \mathrm{mg} \mathrm{U} / \mathrm{L}$ ) and the sorbed uranium can be eluted with dilute phosphoric acid (34). The deacetylated form of chitin, chitosan, has been used to enrich uranium from seawater in other countries (17).

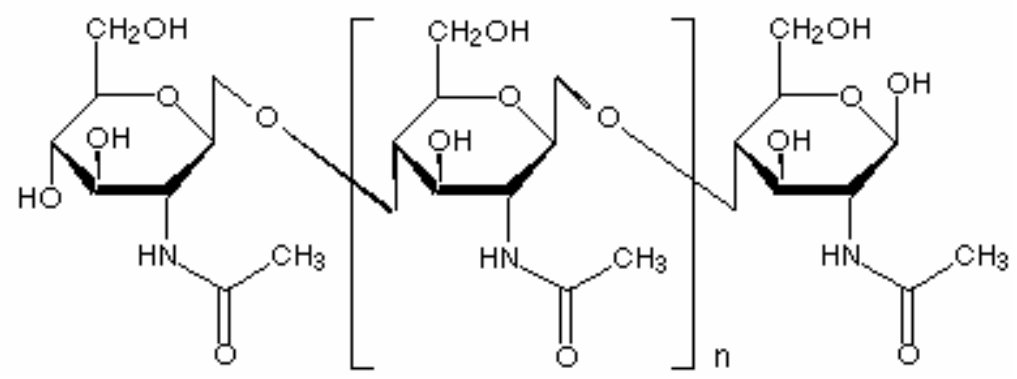

Figure 9. Chitin (its deacetylated form is called chitosan). 


\subsection{European Countries}

\subsubsection{Overview}

Research activities on the extraction of uranium from seawater from a number of European countries are reported in the literature, including Finland (35), France (36-39), Germany (40-58), Greece (59), Italy (60-64), Poland (65), Sweden, and UK (1,66-71). Among the European countries, Germany by far has the largest number of publications and patents on this subject.

As seen in the activities carried out in Japan and other countries, earlier studies (before 1981-1982) in Europe were focused on using hydrous titanium oxide as the sorbents. A number of patents were filed in 1975 - 1984, mostly on the methods and apparatus for the recovery of uranium from seawater based on the sorption by titanate and biomass (72-84). The sorption by titanate looked promising at that time so that the design and layout of an industrial plant were discussed $(44,48,54)$. However, the low mechanical resistance of hydrous titanate materials against attrition resulted in breakdown of the sorbent particles during operation in a fluidized bed. All attempts to produce stronger materials involved serious loss in sorption capacity (48). These disadvantages precluded the further development of the titanate process.

\subsubsection{Studies on amidoxime in Germany}

In earlier 1980s, systematic screening studies of about 200 adsorbents for collection of uranium from seawater were conducted in the Jülich Nuclear Research Centre in Germany. The sorbent materials, including cross-linked resins with different functional groups, were tested on both laboratory scale and large field scale with seawater ( $3 \mathrm{ppb}$ $\mathrm{U})$. The field tests were conducted using $100 \mathrm{~g}$ adsorbent materials fluidized in 1-2 $\mathrm{L}$ columns on the island of Heligoland in the German North Sea and in a test plant located in the Gulf Stream near Miami (Light House Fowey Rocks). The linear velocity of seawater flowing through the columns varied from 0.3 to $1.5 \mathrm{~cm} / \mathrm{s}$, resulting in roughly 24 - 110 s contact time of the seawater with the sorbents (48).

The screening tests indicated that cross-linked poly(acrylamidoximes) were the most promising candidate adsorbents for the extraction of uranium from seawater. The uranium loading on ploy(acrylamidoximes) ranged from hundreds to $3000 \mathrm{ppm}$, which roughly equals to the uranium content of actually explored uranium ores, while most of other materials tested had the uranium loading in the range of a few ppm. Besides, the cross-linked poly(acrylamidoximes) materials were found to have desired properties such as high physical and chemical stability in seawater, as well as fast and selective uptake of uranium $(52,53)$.

The sorbed uranium could be eluted from the cross-linked poly(acrylamidoximes) resin by $1 \mathrm{M} \mathrm{HCl}$. It was observed that the uranium uptake of the resin decreased with increasing number of sorption-elution cycles. At a loss rate in sorption efficiency of $6 \%$ per cycle, the uranium uptake would fall to $50 \%$ of its original value after 11 sorptionelution cycles. Such a rapid breakdown in sorbent performance would very unfavorably affect the process economics. The Jülich studies suggested that two types of functional groups formed during the preparation of the cross-linked resin, an open-chain diamidoxime (Figure 10) and a cyclic imide dioxime (Figure 10). The open-chain diamidoxime was found to be rather stable in $\mathrm{HCl}$ whereas the cyclic imide dioxime turnout to be distinctively more unstable by a factor of 25 . On the other hand, the cyclic imide dioxime is expected to be more effective for complexing $\mathrm{UO}_{2}{ }^{2+}$ in the competition 
with $\mathrm{CO}_{3}{ }^{2-}$ because it can afford a tridentate coordination (Figure 10). The stronger complexing ability and higher instability of the cyclic imide dioxime are probably the reason for the deteriorating performance of the poly(acrylamidoximes) resin during repeated sorption-elution cycles (53).
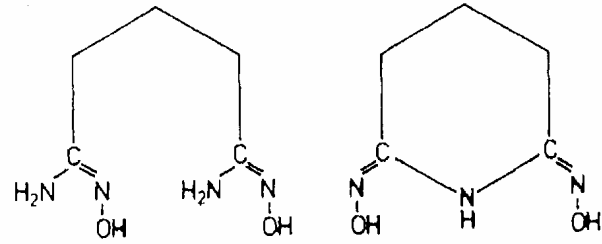<smiles>CO/N=C(/C)N(C)/C(C)=N\OC</smiles>

Figure 10. Open-chain diamidoxime (left), cyclic imide dioxime (center) and its coordination mode (right) (53).

No further R\&D activities in Germany since 1990 on the collection of uranium from seawater by amidoxime-based systems have been found in the literature by this survey.

\section{R\&D Opportunities}

To make the collection of uranium from seawater more economically competitive, the performance of the collection systems, in terms of selectivity, loading capacity, chemical stability and mechanical durability, as well as the sorption kinetics, must be further improved.

\subsection{Understanding the Coordination Modes, the Sorption Mechanism and Kinetics at the Molecular Level}

Though the amidoxime system has been demonstrated to be significantly better in performance for the extraction of uranium from seawater, the nature of the uranium/amidoxime complex, and the extraction mechanism and kinetics are not clearly illustrated. A better understanding of the coordination modes, the sorption mechanism and kinetics is the key to improving the extraction efficiency.

For example, the amidoxime group $-\mathrm{C}\left(\mathrm{NH}_{2}\right) \mathrm{NOH}$ is expected to form a chelate complex with metal ions via the $\mathrm{N}$ atom of the amino group $\left(-\mathrm{C}\left(\mathrm{NH}_{2}\right)\right)$ and the $\mathrm{O}$ atom of the deprotonated $-\mathrm{C}\left(\mathrm{NO}^{-}\right)$group. Crystal structures of the amidoxime complexes with transition metals (Co, $\mathrm{Ni}, \mathrm{Cu}, \mathrm{Pb}$ and $\mathrm{Pt}$ ) have confirmed the formation of such chelate complexes (57). However, in the crystal structure of two amidoxime complexes with $\mathrm{UO}_{2}{ }^{2+}$, the amidoxime ligand was found to be monodentate. As shown in Figure 11, the $\mathrm{O}$ atom of the deprotonated $-\mathrm{C}\left(\mathrm{NO}^{-}\right)$group coordinates to $\mathrm{UO}_{2}{ }^{2+}$ but the $\mathrm{N}$ atom of the amino group $\left(-\mathrm{C}\left(\mathrm{NH}_{2}\right)\right)$ does not (Figure 11) (57). 

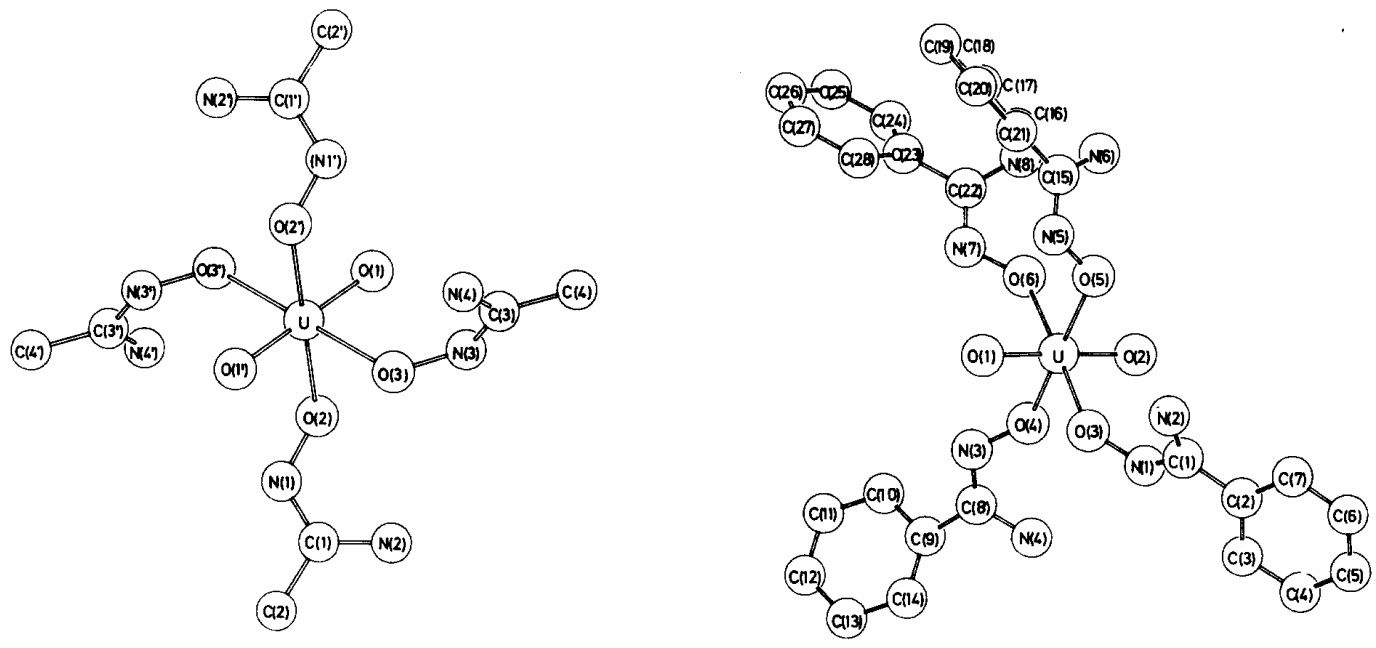

Figure 11. $\left[\mathrm{UO}_{2}(\text { acetamidoxime })_{4}{ }^{2+}\right.$ (left) and $\left[\mathrm{UO}_{2} \text { (benzamidoxime) }\right)_{4}^{2+}$ (left) (57).

The difference in the coordination modes between the transition metals and the uranyl ion may suggest that the softer donor $(\mathrm{N})$ has the higher affinity to transition metals with higher covalency. Such difference should be further investigated and fundamental understanding of the effect could help to design or select ligands with higher selectivity for uranium. Besides, it is unclear how the amidoxime ligands function when grafted on the polyethylene fiber. Studies with spectroscopic techniques (IR, XAS, etc.) could provide insight into the coordination modes of amidoxime complexes with uranium.

Because the dominant uranyl species in seawater are the carbonato complexes (26), the amidoxime must compete with and replace the carbonate groups in the sorption process. Literature reports suggest that the dissociation of the tricarbonato uranyl complex $\left(\mathrm{UO}_{2}\left(\mathrm{CO}_{3}\right)_{3}{ }^{4-}\right)$ is the rate-determining step (85). However, further systematic studies are needed to evaluate the earlier conclusion.

\subsection{Developing Ligands to Improve the Selectivity}

The amidoxime-based fiber extracts uranium, as well as transition metals including $\mathrm{Pb}$, $\mathrm{Fe}, \mathrm{Co}$ and $\mathrm{Ni}$. In fact, the distribution coefficients for the transition metals are all higher than that for $\mathrm{UO}_{2}{ }^{2+}$ (19). R\&D work should be conducted to evaluate other ligands that could have higher selectivity for $\mathrm{UO}_{2}{ }^{2+}$.

Based on the hypothesis that the softer $\mathrm{N}$ donor might be more affinitive toward transition metals than uranyl, ligands with catechol units might have higher affinity toward uranyl than the transition metals. Also, grafting the fibers with ligands such as iminodiacetic acid (IDA) and its derivatives ( $N$-methyl-IDA, dipicolinc acid) may also lead to adsorbents with stronger affinity to uranyl since these tri-dentate ligands could coordinate with uranyl in its equatorial plane without much pre-organization energy.

Grafted polymers with amine-type ligands may also show high efficiency. In a recent study using graft polymerization with amine-type (e.g., ethylenediamine), a distribution coefficient of $2 \times 10^{6}$ for uranyl was observed (6).

Calixarene ligands with catechol units and calyx[4]resorcinarene-hydroxamic acids have shown high selectivity toward uranyl (86-89). In particular, if the calixarene ligand (as 
shown in Figure 7) could be designed so that, in addition to the equatorial coordination with $\mathrm{UO}_{2}{ }^{2+}$, hydrogen bonding could form between the ligand and the axial oxygen(s) of the $\mathrm{UO}_{2}{ }^{2+}$ ion, additional binding strength and selectivity toward uranyl might be achieved.

Engineered biological materials could also be tailored to have high affinity toward uranyl. In a recent study (90), a uranyl-responsive DNA-binding protein was prepared by reengineering the nickel(II)-responsive NikR protein. In the design, the square-planar coordination geometry of the $\mathrm{Ni}^{2+}$ ion in NikR was used as the starting point to construct an equatorial coordination plane for the uranyl core. To achieve a favorable uranyl coordination environment, His76 and Cys95 were mutated to aspartic acid (H76D C95D), which can coordinate either in a monodentate or a bidentate fashion. To accommodate the uranyl oxo groups, Val72 was mutated to serine (V72S), which has the potential to form a hydrogen bond to one of the oxo groups of the uranyl cation (Figure 12). Such studies, in a long run, may lead to the preparation of biomaterials with engineered protein for specific collection of uranium from seawater, or for environmental remediation purposes.

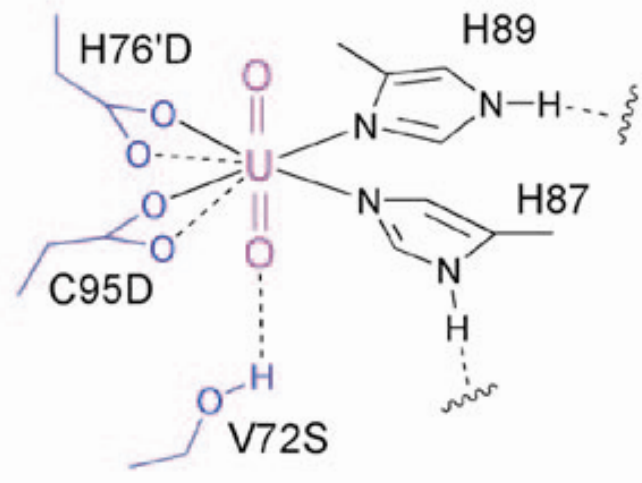

Figure 12. Engineered NikR protein for selective binding of $\mathrm{UO}_{2}{ }^{2+}(90)$.

It should be emphasized that, to be applicable to the extraction of uranium from seawater, the ligands should be robust and simple, easy and less costly to make on a large scale, and have a fast sorption rate. A balance between these properties and the selectivity must be achieved.

\subsection{Developing New Materials to Improve the Chemical Stability, Mechanical Durability, and the Sorption Kinetics of the Sorbents}

To make the collection of uranium from seawater economically competitive, the sorbents must be stable and durable during repeated sorption/elution cycles. One of the major reasons for the failure of the $\mathrm{TiO}_{2}$ sorption systems is the serious loss of the material in the collection process. The performance of the amioxime-based sorbents was also found to deteriorate after repeated use - successful reuse for 8 times has been achieved but a repetition of 18 times could reduce the collection cost by more than $20 \%$ (19).

Better techniques for functionalizing the fiber materials could increase the density as well as the binding strength of the ligands on the fiber. In addition, improved synthetic routes could help to prepare the sorbents with higher yield of the preferred configuration to allow uranyl chelate complex formation (e.g., the cyclic imide dioximes in Figure 10). Besides, if the cyclic dioximes are indeed the preferred configuration, means to protect them from breaking down in acidic elution could significantly increase the reusability of the amidoxime-based sorbents. 
Though the non-woven polyethylene fiber has been used in marine experiments with some success, its hydrophobicity might adversely affect the sorption rate of ionic species such as uranium $\left(\mathrm{UO}_{2}\left(\mathrm{CO}_{3}\right)_{3}{ }^{4-}\right.$, etc.). Previous studies aiming at improving the sorption kinetics include the preparation of hydrophilic amidoxime fibers by co-grafting multiple ligands (9), the preparation of hydrogels containing various acidic ligands (24) and the use of cellulose or cellulose-like materials (e.g., chitosan Figure 9) (17). The rapid advances of nanotechnology in recent years are expected to help develop novel materials for applications in the collection of uranium in seawater.

Use of biomass for the collection of uranium is another area that should be investigated. Previous studies have shown that the concentration factor of biomass such as algae for uranium in seawater is about 200 (18), which is too low for practical applications. Development of Innovative biomaterials with engineered protein (such as that shown in Figure 12 could significantly increase the concentration factor and make bio-collection practical.

\subsection{Developing Innovative Elution Processes to Improve the Elution Efficiency and Minimize Loss of Sorbents}

The loss and deterioration of sorbents in the elution process (e.g, with $1 \mathrm{M} \mathrm{HCl}$ for the amidoxime-based systems) is a significant factor that limits the economical competitiveness of current collection systems. Innovative elution processes should be studied. For example, application of supercritical fluid $\mathrm{CO}_{2}$ extraction of uranium from sorbents loaded with uranium is an area worth investigating.

\section{References}

1. R. V. Davies, J. Kennedy, R. W. Mcllroy, R. Spence, K. M. Hill, Extraction of uranium from seawater. Nature, 203 (1964) 1110-1115.

2. K. Saito. Japanese research plant for uranium from sea-water, Nuclear Engineering International, 25 (1980) 32-33.

3. M. Kanno, Present Status of Study on Extraction of Uranium from Sea Water, Journal of Nuclear Science and Technology, 21 (1984) 1-9.

4. Tabushi, Y. Kobuke, T. Nishiya, Extraction of uranium from seawater by polymer-bound Macrocyclic hexaketone, Nature, 280 (1979) 665-666.

5. http://www.taka.jaea.go.jp/eimr div/j637/paper e.html. List of 36 publications on the development of polymer-based metal adsorbents by the Environmental Polymer Group of JAEA.

6. N. Seko, L.T. Bang and M. Tamada, Syntheses of amine-type adsorbents with emulsion graft polymerization of glycidyl methacrylate, Nucl. Instr. and Meth. B, 265 (2007) 146-149.

7. P. A. Kavakli, N. Seko, M. Tamada and O. Guven, Adsorption efficiency of a new adsorbent towards uranium and vanadium ions at low concentrations, Sep. Sci. Technol., 39 (2004) 1631-1643.

8. A. Zhang , T. Asakura, G. Uchiyama, The adsorption mechanism of uranium(VI) from seawater on a macroporous fibrous polymeric adsorbent containing amidoxime chelating functional group, Reactive \& Functional Polymers, 57 (2003) 67-76.

9. T. Kawai, K. Saito, K. Sugita, T. Kawakami, J. Kanno, A. Katakai, N. Seko, T. Sugo, Preparation of hydrophilic amidoxime fibers by cografting acrylonitrile and methacrylic acid from an optimized monomer composition, Radiation Physics and Chemistry, 59 (2000) 405411 
10. Y. Y. Park, S. Y. Kim, J. S. Kim, M. Harada, H. Tomiyasu, M. Nogami, Y. Ikeda, Complex formation of $\mathrm{U}(\mathrm{VI})$ with benzamidoxime in non-aqueous solvents, J. Nuclear Science \& Technology, 37 (2000) 344-348.

11. T. Hirotsu, S. Katoh, K. Sugasaka, M. Sen, T. Itagaki, Adsorption Equilibrium of Uranium from Aqueous $\left[\mathrm{UO}_{2}\left(\mathrm{CO}_{3}\right)_{3}\right]^{4-}$ Solutions on a Polymer bearing Amidoxime Groups, J. CHEM. SOC. DALTON TRANS. (1986) 1983.

12. N. Kabay, H. Egawa, Recent advances in the development of chelating polymers for recovery of uranium from seawater. Turkish Journal of Chemistry, 17 (1993) 62-73.

13. N. Kabay, H. Egawa, Chelating polymers for recovery of uranium from seawater. Separation Science and Technology, 29 (1994), 135-50.

14. N. Kabay, Preparation of amidoxime-fiber adsorbents based on poly(methacrylonitrile) for recovery of uranium from seawater. Separation Science and Technology, 29 (1994), 375-84.

15. N. Kabay, A. Katakai, T. Sugo, Preparation of amidoxime-fiber adsorbents by radiationinduced grafting. Radiation Physics and Chemistry, 46 (1995), Proceedings of the 9th International Meeting on Radiation Processing, 1994, Pt.1, pp.833-6.

16. N. Kabay, N.; Egawa, H. Adsorption-elution behaviors of lightly crosslinked porous amidoxime resins for uranium recovery from seawater. Special Publication - Royal Society of Chemistry (1997), 196(Progress in lon Exchange), 378-382.

17. K. Oshita, A. Sabarudin, T. Takayanagi, M. Oshimac, S. Motomizu, Adsorption behavior of uranium $(\mathrm{VI})$ and other ionic species on cross-linked chitosan resins modified with chelating moieties, Talanta, 79 (2009) 1031-1035.

18. N. Sakamoto, N. Kano, and H. Imaizumi, Biosorption of Uranium and Rare Earth Elements Using Biomass of Algae, Bioinorganic Chemistry and Applications, 2008, doi:10.1155/2008/706240.

19. M. Tamada, "Current Status of Technology for Collection of Uranium from Seawater," Japan Atomic Energy Agency, 2009.

20. N. Seko, A. Katakai, S. Hasegawa, M. Tamada, N. Kasai, H. Takada, T. Sugo, K. Saito, Aquaculture of uranium in seawater by fabric-adsorbent submerged system, Nuclear Technology, 144 (2003) 274-278.

21. http://www.telegraph.co.uk/news/worldnews/asia/japan/5550284/Japan-plans-underwatersponges-to-soak-up-uranium.html (website accessed on 2/10/2010)

22. Private communication.

23. S. Das, A. K. Pandeylc, V.K. Manchandab, Chemical aspects of uranium recovery from seawater by amidoximated electron-beam-grafted polypropylene membranes, Desalination, 232 (2008) 243-253.

24. S. Das, A. K. Pandey, T. Vasudevan, A. A. Athawale, and V. K. Manchanda, Adsorptive preconcentration of uranium in hydrogels from seawater and aqueous solutions, Ind. Eng. Chem. Res., 48 (2009) 6789-6796.

25. H. Sodaye, S. Nisan, C. Poletiko, S. Prabhakar, P. K. Tewari, Extraction of uranium from the concentrated brine rejected by integrated nuclear desalination plants, Desalination, 235 (2009) 9-32.

26. K. Saito and T. Miyauchi, Chemical Forms of Uranium in Artificial Seawater, J. Nucl. Sci. and Tech., 19 (1982) 145-150.

27. P. K. Tewari, Recovery of Uranium from Sea Water, Chemical Sciences \& Engineering, BARC HIGHLIGHTS (2006-2007) 53. 
28. http://baike.baidu.com/view/366254.htm?fr=ala0 1 (website accessed on 2/10/2010)

29. S. Chen, W. Liao, X. Xu, Kinetic study of the extraction of uranium from seawater using $\mathrm{TiO}_{2}-$ gel: I - determination of the activation energy of sorption, Haiyangxuebao (Chinese), 1 (1981).

30. S. Chen, W. Liao, X. Huang, J. Tang, Kinetic study of the extraction of uranium from seawater using $\mathrm{TiO}_{2}$-gel: II - mechanism of sorption, Haiyangxuebao (Chinese), 4 (1981).

31. S. Chen, $A, X u, X$. Huang, J, Xu, C. Tian, Kinetic study of the extraction of uranium from seawater using $\mathrm{TiO}_{2}$-gel: III - diffusion mechanism of the exchange process, Haiyangxuebao (Chinese), 2 (1982).

32. H. Ai, S. Chen, Z. Tao, Z, Lin, Equilibium and kinetics of the sorption by ion exchange mechanism of the extraction of uranium from seawater, Wulihuaxuexuebao (Chinese), 1 (1989).

33. K. Jin, S. Yu, C. Gao, Current Status of the extraction of uranium from seawater, Haiyangxuebao (Chinese), 2 (2001).

34. http://ads.0030.net/jiagong10.html (website accessed on 2/26/2010)

35. O. J. Heinonen, Sorption of uranyl ions from sea water on sodium titanate. Radiochemical and Radioanalytical Letters, 43 (1980) 293-9.

36. V. Ziegler, Nonconventional sources of uranium and associated extraction techniques. Round table on uranium provisions and supply. Revue de l'Energie, 309 (1978) 586-92.

37. N. Jaffrezic-Renault, H. Andrade-Martins, Study of the retention mechanism of uranium on titanium oxide. Journal of Radioanalytical Chemistry, 55 (1980) 307-16.

38. H. Tbal, J. Morcellet, M. Delporte, M. Morcellet, Uranium absorption by chelating resins containing amino groups. Journal of Macromolecular Science, Pure and Applied Chemistry, A29 (1992) 699-710.

39. A. Favre-Reguillon, G. Lebuzit, J. Foos, A. Guy, M. Draye, M. Lemaire, Selective concentration of uranium from seawater by nanofiltration, Ind. Eng. Chem. Res. 42 (2003) 5900-5904.

40. G. Lange, New possibilities for exploration of uranium. Reaktortagung, 7th (1975), 307-10. Publisher: Dtsch. Atomforum E. V., Bonn, Germany.

41. H. G. Bals, Uranium extraction from seawater. INIS. Report (1976), (INIS-mf-3844), 149 pp. From: INIS Atomindex 1977, 8(20), Abstr. No. 334731.

42. K. Schwochau, L. Astheimer, H. J. Schenk, Process for the recovery of uranium from sea water. Ber. Kernforschungsanlage Juelich (1977), (Juel-1415), 71 pp.

43. F. Ambe, P. Burba, K. H. Lieser, Sorption rate of uranyl ions by Hyphan cellulose exchangers and by hydrated titanium dioxide. Fresenius' Zeitschrift fuer Analytische Chemie, 295 (1979) 13-16.

44. P. H. Koske, Uranium recovery from the ocean. The layout of an industrial plant with respect to the concept of fluidized adsorber beds. Ges. Kernenergieverwert. Schiffbau Schiffahrt, [Ber.] (1979), (GKSS 79/E/14), 33 pp.

45. P. H. Koske, Extraction of uranium from sea water. Uranium and Nuclear Energy, 4 (1979) 111-17.

46. K. Schwochau, Uranium from sea water. Technik und Laboratorium, 27 (1979) 563-4, 566-7.

47. K. Wagener, D. Heitkamp, Humic acids as promising adsorbents for recovering uranium from seawater. Thalassia Jugoslavica, 16 (1980) 185-9.

48. P. H. Koske, K. Ohlrogge, Uranium production from the sea. Considerations on the layout of 
a plant on the basis of fluidized adsorber beds with active water transport (pump concept alternative). Report (1981), (GKSS-81/E/9), 16 pp. From: INIS Atomindex 1981, 12(15), Abstr. No. 615836.

49. K. Schwochau, L. Astheimer, H. J. Schenk, E. G. Witte, On the extraction of uranium from seawater by a complexing resin. Zeitschrift fuer Naturforschung, Teil B: Anorganische Chemie, Organische Chemie, 37B (1982) 214-16.

50. K. H. Lieser, B. Gleitsmann, Separation of heavy metals, especially uranium, from seawater by use of anchor groups of high selectivity. I. Batch experiments. Fresenius' Zeitschrift fuer Analytische Chemie, 313 (1982) 203-7.

51. D. Heitkamp, K. Wagener, New aspects of uranium recovery from seawater. Industrial \& Engineering Chemistry Process Design and Development, 21 (1982) 781-4.

52. H. J. Schenk, L. Astheimer, E. G. Witte, K. Schwochau, Development of sorbers for the recovery of uranium from seawater. 1. Assessment of key parameters and screening studies of sorber materials. Sep. Sci. Technol., 17 (1982) 1293-1308.

53. L. Astheimer, H.J. Schenk, E.G. Witte, and K. Schwochau, Development of sorbers for the recovery of uranium from seawater. Part 2. Sep. Sci. Technol., 18 (1983) 307-339.

54. P. H. Koske, K. Ohlrogge, K. Influence of adsorber performance on plant design for the extraction of uranium from seawater. Report (1983), (GKSS-82/E/57; Order No. DE84751538), 16 pp. From: Energy Res. Abstr. 1984, 9(24), Abstr. No. 49508.

55. K. Schwochau, L. Astheimer, H. J. Schenk, E. G. Witte, Problems and results of uranium recovery from seawater. Chemiker-Zeitung, 107 (1983) 177-89.

56. H. J. Fischer, K. H. Lieser, Selective separation of uranium from simulated seawater on a cellulose exchanger with 8-oxa-2,4,12,14-tetraoxopentadecane as chelate-forming anchor group. Angewandte Makromolekulare Chemie, 112 (1983), 1-14.

57. E. G. Witte, K. S. Schwochau, G. Henkel, B. Krebs, Uranyl complexes of acetamidoxime and benzamidoxime, preparation, characterization and crystal structure. Inorganica Chimica Acta, 94 (1984) 323-331.

58. P. H. Koske, K. Ohlrogge, K. V. Peinemann, Uranium recovery from seawater by adsorption. Separation Science and Technology, 23 (1988) 1929-40.

59. Ochsenkuhn-Petropulu, M.; Parissakis, G. The application of the ion-exchanger SRAFION NMRR for the enrichment and separation of uranium and other trace elements from seawater. Fresenius' Zeitschrift fuer Analytische Chemie (1985), 321(6), 581-6.

60. L. Cattalini, U. Croatto, S. Degetto, G. Marangoni, On the separation of uranium from very dilute aqueous solutions. Atti della Accademia Peloritana dei Pericolanti, Classe di Scienze Fisiche, Matematiche e Naturali, 54 (1974) 217-19.

61. C. Bettinali, F. Pantanetti, Uranium from sea-water: possibilities of recovery, exploiting slow coastal currents. Uranium Ore Process., Proc. Advis. Group Meet. (1976), pp.213-31. Publisher: IAEA, Vienna, Austria.

62. A. F. Casa, Uranium from ocean water. Notiziario - Comitato Nazionale per l'Energia Nucleare (Italy), 27 (1981) 63-6.

63. R. A. A. Muzzarelli, Removal of uranium from solutions and brines by a derivative of chitosan and ascorbic acid. Carbohydrate Polymers, 5 (1985) 85-9.

64. R. A. A. Muzzarelli, The chelating ability of amino acid glucans and sugar acid chitosans. Editor(s): R. A. A. Muzzarelli, C. Jeuniaux, G. W. Gooday, Chitin Nat. Technol., [Proc. Int. Conf. Chitin Chitosan], 3rd (1986), pp.321-30. Publisher: Plenum, New York, N. Y.

65. W. Walkowiak, W. Charewicz, The application of adsorptive bubble separation methods to wastewater treatment and recovery of trace elements. Environment Protection Engineering, 3 
(1977) 25-46.

66. G. I. W. Llewelyn, Extraction of uranium from sea-water. Atom, 238 (1976) 214-219.

67. F. Vernon, Uranium from the sea. Tool \& Alloy Steels, 21 (1987) 343-5.

68. F. Vernon, T. Shah, The extraction of uranium from seawater by poly(amidoxime)/poly(hydroxamic acid) resins and fiber. Reactive Polymers, Ion Exchangers, Sorbents, 1 (1983) 301-8.

69. F. Vernon, H. Cameron, L. Georghiou, Prospects for the extraction of uranium from seawater. Institution of Chemical Engineers Symposium Series, 78 (1982), (Energy: Money, Mater. Eng.), A/61-A/66.

70. N. J. Keen, Recovery of uranium from sea water. Chemistry \& Industry (London, United Kingdom), 14 (1977) 579-82.

71. F. Vernon, H. Eccles, Chelating ion-exchangers containing N-substituted hydroxylamine functional groups. Part IV. Column separations on a hydroxamic acid resin. Analytica Chimica Acta, 83 (1976) 187-93.

72. Kernforschungsanlage Juelich G..m..b..H., Fed. Rep. Ger. Apparatus and method for extracting uranium from sea water. Fr. Demande (1975), 7 pp. CODEN: FRXXBL FR 224326419750404

73. E. A. Heide, M. Paschke, K. Wagener, M. Wald, (Kernforschungsanlage Juelich G..m..b..H., Fed. Rep. Ger.), Matrix of cultivable mutants of single-cell green algae for uranium recovery from sea water. Ger. Offen. (1975), 5 pp. CODEN: GWXXBX DE 234543019750417

74. H. G. Bals, (Uranerzbergbau-G..m..b..H. und Co. K.-G., Fed. Rep. Ger.). Apparatus and method for recovering dissolved, suspended, or chemically bound materials from a liquid. Ger. Offen. (1977), 20 pp. CODEN: GWXXBX DE 255075119770526

75. Kernforschungsanlage Juelich G..m..b..H., Fed. Rep. Ger. Matrix for adsorbing substances from a gas or solution. Fr. Demande (1978), 8 pp. CODEN: FRXXBL FR 237195919780623

76. L. Astheimer, H. J. Schenk, K. Schwochau, (Kernforschungsanlage Juelich G..m..b..H., Fed. Rep. Ger.). Recovery of uranium from sea water or comparable solutions. Ger. Offen. (1978), 13 pp. CODEN: GWXXBX DE 272283819781123

77. D. Heitkamp, K. Wagener, (Kernforschungsanlage Juelich G..m..b..H., Fed. Rep. Ger.). Recovering dissolved heavy metals from seawater. Ger. Offen. (1978), 24 pp. CODEN: GWXXBX DE 271160919780921

78. Kernforschungsanlage Juelich G..m..b..H., Fed. Rep. Ger. Microorganism cultures for extracting uranium from seawater. Brit. (1978), 3 pp. Addn. to Brit. 1,472,626. CODEN: BRXXAA GB 150700319780412

79. R. Lesser, (European Atomic Energy Community (Euratom), Luxembourg). Device and methods for recovery of dissolved, suspended or chemically bound substances from a liquid. Ger. Offen. (1980), 9 pp. CODEN: GWXXBX DE 290096619800724

80. H. G. Bals, (Uranerzbergbau-G..m..b..H., Fed. Rep. Ger.). Recovery of uranium from seawater. Ger. Offen. (1980), 18 pp. CODEN: GWXXBX DE 284205819800410

81. G. E. Lagstroem, S. Forberg, E. G. T. Westermark, (Swed.). Method and apparatus for gathering valuable floating, dissolved and suspended substances from sea water. Eur. Pat. Appl. (1980), 12 pp. CODEN: EPXXDW EP 1834019801029 
82. U. Zimmermann, G. Pilwat, (Kernforschungsanlage Juelich G..m..b..H., Fed. Rep. Ger.). Mass and a method of preparing same of living cells of organisms for adsorbing metal ions from a physiological solution. U.S. (1981), 5 pp. Cont.-in-part of U.S. Ser. No. 753,474, abandoned. CODEN: USXXAM US 429240819810929

83. P. Koske, K. Ohlrogge, (GKSS-Forschungszentrum Geesthacht G..m..b..H., Fed. Rep. Ger.). Recovery of uranium from seawater. Ger. Offen. (1981), 16 pp. CODEN: GWXXBX DE 293639919810402 (Kernforschungsanlage Juelich G.m.b.H., Fed. Rep. Ger.). Ger. Offen. (1982), 9 pp. CODEN: GWXXBX DE 3047220 A1 19820624

84. H. P. Koske, K. Ohlrogge, (GKSS-Forschungszentrum Geesthacht G..m..b..H., Fed. Rep. Ger.). Method and apparatus for recovery of uranium and other materials from seawater. Ger. Offen. (1984), 21 pp. CODEN: GWXXBX DE 3241497 A1 19840510

85. T. Aihara, A. Goto, T Kago, K. Kusakabe, S. Morooka, Rate of adsorption of uranium from seawater with a calix[6]arene adsorbent. Separation Sci. Tech., 27 (1992) 1655-1667.

86. A. Leydier, D. Lecercle, S. Pellet-Rostaing, A. Favre-Reguillon, F. Taran, M. Lemire, Sequestering agents for uranyl chelation: new calixarene ligands. Tetrahedron, 64 (2008) 1319-11324.

87. K. Jain, S. G. Pillai, R. A. Pandya, Y. K. Agrawal, P. S. Shrivastav, Molecular octopus: octa functionalized calyx[4]resorcinarene-hydroxamic acid [C4RAHA] for selective extraction, separation and preconcentraion of U(VI). Talanta, 65 (2005) 466-475.

88. J. M. Harrowfield, M. I. Ogden, A. H. White, Actinide complexes of the calixarenes. 1. Syntheses and crystal structures of bis(homo-oxa)-para-tert-butylcalixarene and its uranyl ion complex. J. Chem. Soc. Dalton Trans., (1991) 979-985.

89. K. Schmeide, K. H. Heise, G. Bernhard, D. Keil, K. Jansen, D. Praschak, Uranium (VI) separation from aqueous solution by calyx[6]arene modified textiles. J. Radioanal. Nucl. Chem., 261 (2004) 61-67.

90. S. V. Wegner, H. Boyaci, H. Chen, M. P. Jensen, C. He, Engineering a uranyl-specific binding protein from NikR source. Angewandte Chemie-International Edition, 48 (2009) 23392341. 